NBER WORKING PAPER SERIES

\title{
BOND MARKET INFLATION EXPECTATIONS IN INDUSTRIAL COUNTRIES: HISTORICAL COMPARISONS
}

\author{
Michael Bordo \\ William G. Dewald \\ Working Paper 8582 \\ http://www.nber.org/papers/w8582 \\ NATIONAL BUREAU OF ECONOMIC RESEARCH \\ 1050 Massachusetts Avenue \\ Cambridge, MA 02138 \\ November 2001
}

Michael D. Bordo is a Professor of Economics at Rutgers University. He is a consultant at the Federal Reserve Bank of St. Louis and a Research Associate at the National Bureau of Economic Research. William G. Dewald is retired from the Federal Reserve Bank of St. Louis, the U.S. State Department, and Ohio State University. He teaches part time at Northern Arizona University. The views expressed herein are those of the authors and not necessarily those of the National Bureau of Economic Research.

(C) 2001 by Michael Bordo and William G. Dewald. All rights reserved. Short sections of text, not to exceed two paragraphs, may be quoted without explicit permission provided that full credit, including $(\mathrm{C}$ notice, is given to the source. 
Bond Market Inflation Expectations in Industrial Countries: Historical Comparisons Michael Bordo and William G. Dewald

NBER Working Paper No. 8582

November 2001

JEL No. E42, E43

\begin{abstract}
We define the Fisherian Golden Rule measure of bond market inflation expectations as the difference between bond rates and trend real GDP growth rates. The concept is based on the Fisherian theory that an increase in longer-term inflation expectations would be reflected in longer-term interest rates and the Golden Rule theory that in longer-term equilibrium the real rates of interest would equal the growth rate of real output. We compare the bond market inflation experiences of 13 advanced countries for the 1881-1913 gold standard era with the experience of the recent 1962-1995 period. The difference between average longer-term bond rates and average real GDP growth rates reflected the widespread expectation of low inflation during 1881-1913 in all of the industrial countries. Although real GDP growth was somewhat higher on average during 1962-65 than 1881-1913, bond rate averages were considerably higher, roughly comparable with the higher observed inflation rates. Long-term bond rates fell across the spectrum of the industrial countries in the 1980s and 1990s and bond market expectations for low inflation were substantially, but not fully regained for the industrial countries as a group.
\end{abstract}

Michael D. Bordo

Department of Economics

Rutgers University

New Brunswick, NJ 08901

and NBER

bordo@economics.rutgers.edu
William G. Dewald 235 Rim Shadows Drive Sedona, AZ 86336-3458

dewald@sedona.az.net 


\section{INTRODUCTION}

Inflation has been low in recent years. Yet bond markets in industrial countries have not fully reflected it. Certainly not in the United States where government bond rates in 2001 were higher than they ever were before the mid 1960s. Chart 1 reveals the systematic association between government bond rates and inflation in U.S. data from 1962 through 1999. Inflation rose in three spurts in the1960s and 1970s and then fell sharply in the 1980s. The gap between the bond rate and, not annual inflation, but average inflation over the previous ten years roughly approximates the U.S. real GDP growth trend which is also plotted. It is this simple association in the data that is explored in the present paper for the United States and other highly industrialized countries, and for both recent decades and a period of comparable length before World War I. Although individual country data are the essential elements of the analysis, our focus is on the average patterns across these major industrial countries with respect to inflation, longer-term interest rates, real growth rates, and our calculations of the inflationary expectations that are implicit in bond rates. 


\section{Chart 1. U.S. Inflation and 10-Year Government Bond Rates, 1962-1999}

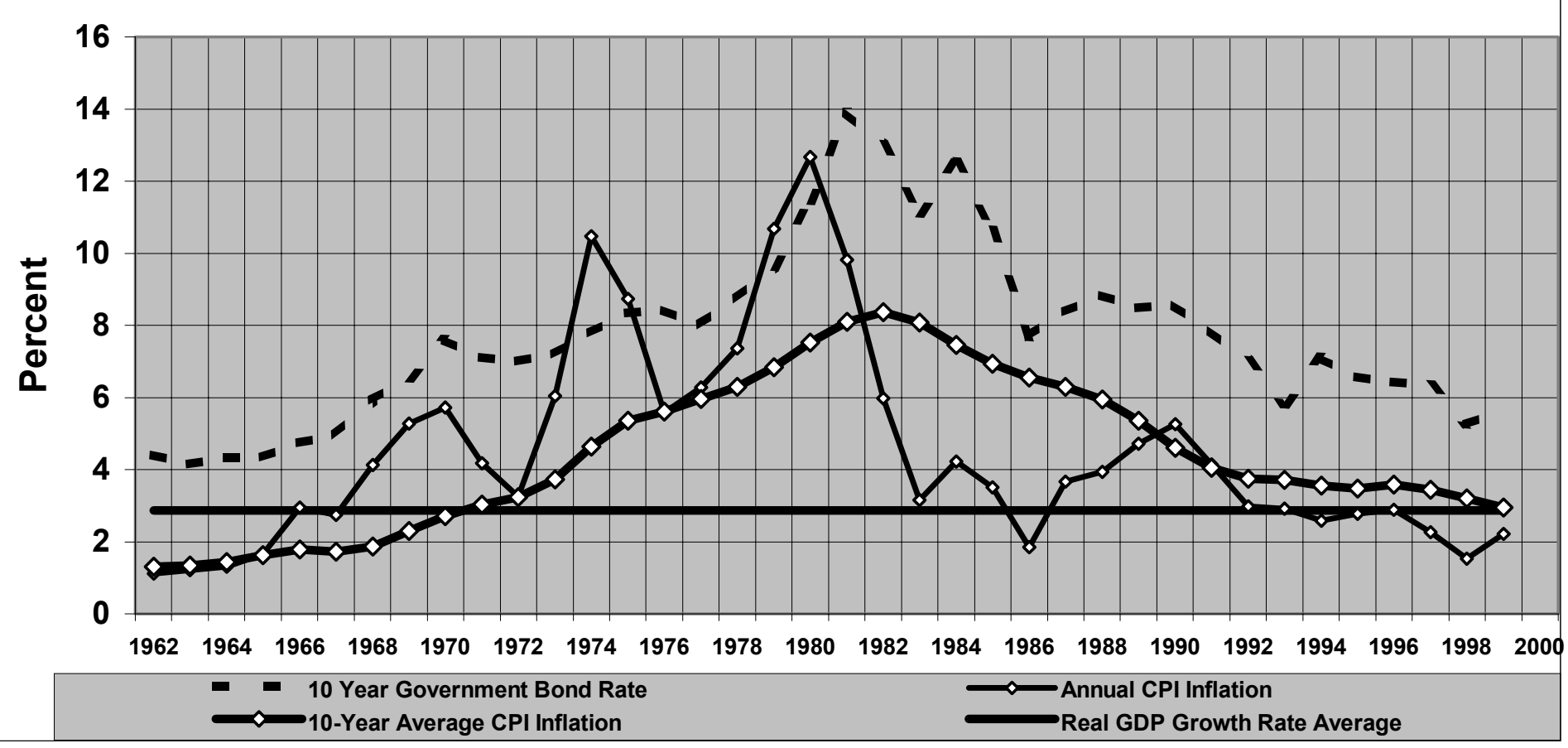

The two periods studied are the thirty-three years before World War I, 1881-1913, and the thirty-three years beginning with the take off of inflation in the1960s, 1963-1995. In the first period near zero inflation was generally observed. It was the hey-day of a fixed exchange rate international monetary system under the gold standard. Year-to-year price level changes were highly volatile, but bond rates were remarkably stable. In the second period, pressures on the U.S. dollar developed leading to the demise of the post-World War II Bretton Woods fixed exchange rate system in the early 1970s. It was a period when fiat monetary standards were established with no brake on inflation in a country except the performance of its central bank In the 1960s and 1970s, the inflation trend turned up substantially across the world, but then turned down after the early 1980 s.

Although bond rates followed these inflation trends up and down, in neither period did the bond market foresee impending changes in inflation trends. The surge in inflation in World War I was not incorporated in bond rates before the war. The acceleration in inflation in the 1970s was not sufficiently incorporated in bond rates in the 1960s and early 1970s. Neither was the deceleration of inflation that occurred subsequently. Thus, inflation expectations imbedded 
in bond rates appear to have adapted reasonably well to past inflation, but, as a consequence, bond market inflation expectations have systematically underestimated rising inflation trends and overestimated falling inflation trends. The paper concludes that central banks in the 1990s had much less credibility in bond markets to keep inflation low than had existed in the mid 1960s at the advent of the subsequent long cycle of inflation and disinflation. And none had the kind of credibility to keep price levels stable in the long run that existed before World War I.

\section{BOND MARKET INFLATION EXPECTATIONS}

Theoretically, bond rates would increase with an increase in either expected inflation or expected real output growth - a proxy for the real rate of interest. Hence, given other factors, the difference between bond rates and trend real GDP growth rates -- such as was illustrated in Chart 1 -- is a measure of bond market inflation expectations. The concept is based on the Fisherian theory that an increase in longer-term inflation expectations would be fully reflected in longer-term interest rates ${ }^{2}$. It is also based on the Golden Rule theory that in a longer-term equilibrium, the real rate of interest would equal the rate of real output growth ${ }^{3}$. According to that theory expected future real returns on investments would be a function of expected future real output growth which would increase the demand for credit to finance investment and raise longer-term interest rates.

Although there are a variety of tax, regulation, and risk factors that also influence bond rates, this paper focuses on the simple Fisherian-Golden Rule hypothesis that nominal

\footnotetext{
2 "The fact that interest expressed in money is high, say 15 per cent, might conceivably indicate merely that general prices are expected to rise (i.e., money depreciate) at the rate of 10 per cent, and that the rate of interest expressed in terms of goods is not high, but only about 5 per cent." Irving Fisher The Theory of Interest, Reprints of Economic Classics, Augustus M. Kelly, 1961, pp. 41-42.

${ }^{3}$ This is a common assumption in both theoretical and empirical studies. In formulating his "Taylor Rule", John Taylor (1993), for example, set the equilibrium short-term interest rate at the trend growth in real income because this value is approximately equal to potential growth, i.e. compatible with a long-term equilibrium growth path.
} 
government bond rates would vary directly with both expected real output growth and expected inflation over the maturity of the bonds.

\section{THE VARIABLES, COUNTRIES, AND PERIODS}

The data we focus on include consumer price inflation, ten-year government bond rates, and real GDP growth. We have data for thirteen major industrial countries: Canada, France, Germany, Italy, Japan, Netherlands, Sweden, Switzerland, United Kingdom, and United States which make up the G10, plus Belgium, Denmark, and Norway. Annual data are available with few exceptions. The missing data are bond rates for Japan and real GDP for Belgium during 1881-1913, and inflation for Belgium during 1915-1919, a period for which their ten-year bond rates through 1913 incorporated an implicit inflation expectation.

The periods 1881-1913 and 1963-1995 are similar insofar as each represents a relatively stable international monetary and political order for the thirteen countries. The intervening five decades that have been left out include the disruptions of two World Wars, the Great Depression of the inter-war period, and the post World War II transition to a more open international investment and trading order in the 1960s. By contrast, both 1881-1913 and 1963-1995 were periods characterized by considerable freedom for capital to flow across national borders. In the earlier period, capital movements integrated domestic monetary systems and price levels under the gold standard. The link to gold was totally abandoned under the post-1973 floating exchange rate system.

The following tables and charts present the annual statistics on which the analysis is based: CPI inflation, ten-year government bond rates, real GDP growth, and the difference between bond rates and real GDP growth rate trends which is our measure of bond market inflation expectations over the maturity of the bonds. 


\section{INFLATION COMPARISONS}

Table 1 records individual country consumer-price inflation means and standard deviations for the two periods and overall averages. Inflation overall was close to zero in the first period, but nearly 6 percent in the recent period. It was comparably variable in each period.

Japan was an exception to the low inflation pattern before World War I. Its inflation averaged 2.27 percent. In the other major industrial countries, inflation averaged 0.35 percent overall and ranged from -0.26 percent to +0.83 percent. The comparatively high inflation in Japan is attributable to its being on a silver standard during the early part of the period which allowed it to avoid deflations in the gold standard world of other countries.

Table 1. Annual Consumer Price Inflation
\begin{tabular}{|l|c|c|c|c|}
\hline Country & \multicolumn{2}{|c|}{1881913} & \multicolumn{2}{c|}{$1963-1955$} \\
\hline & Mean & Std Dev & Mean & Std Dev \\
\hline & & & & \\
\hline USA & 0.07 & 2.11 & 4.90 & 2.85 \\
\hline UK & -0.09 & 2.53 & 7.29 & 4.86 \\
\hline Germany & 0.83 & 2.40 & 3.43 & 1.75 \\
\hline France & 0.13 & 1.25 & 5.94 & 3.57 \\
\hline Japan & 2.27 & 5.27 & 4.76 & 4.14 \\
\hline Canada & 0.64 & 4.03 & 5.18 & 3.03 \\
\hline Italy & 0.03 & 2.20 & 8.43 & 5.16 \\
\hline Belgium & 0.03 & 4.97 & 4.69 & 2.78 \\
\hline Netherlands & -0.26 & 3.70 & 4.43 & 2.65 \\
\hline Switzerland & -0.16 & 3.72 & 3.77 & 2.13 \\
\hline Denmark & 0.16 & 3.65 & 6.28 & 3.25 \\
\hline Norway & 0.55 & 3.25 & 6.12 & 3.00 \\
\hline Sweden & 0.37 & 3.19 & 6.50 & 2.98 \\
\hline & & & & 3.24 \\
\hline Mean & 0.35 & 3.25 & 5.52 & \\
\hline
\end{tabular}

In contrast to low inflation during 1881-1913, there was significant consumer price inflation in each country during 1963-1995. There was also a wider difference in inflation rates 
across countries. During the recent period, inflation was lowest in Germany and Switzerland, but, even there, it was not low, averaging respectively 3.43 percent and 3.77 percent. The nations with the highest inflation were Italy at 8.43 percent and the United Kingdom at 7.29 percent. The cross-country average was 5.52 percent.

Table 2 shows that the consumer price levels on average increased about 12 percent from 1880 through 1913 compared with 182 percent from 1962 through 1995 . In the earlier period the price level was virtually stable in the United Kingdom and several other countries. By contrast from 1962 through 1995 price level increases ranged from a low of 113 percent in Germany to a high of 278 percent in Italy.

\begin{tabular}{|c|c|c|}
\hline Country & $1880-1913$ & $1962-1955$ \\
\hline USA & 2.39 & 161.70 \\
\hline UK & -2.96 & 240.64 \\
\hline Germany & 27.44 & 113.15 \\
\hline France & 4.17 & 196.12 \\
\hline Japan & 75.07 & 157.17 \\
\hline Canada & 21.13 & 170.88 \\
\hline Italy & 1.01 & 278.33 \\
\hline Belgium & 1.01 & 154.92 \\
\hline Netherlands & -8.62 & 146.23 \\
\hline Switzerland & -5.44 & 124.27 \\
\hline Denmark & 5.13 & 207.31 \\
\hline Norway & 18.23 & 202.07 \\
\hline Sweden & 12.09 & 214.53 \\
\hline Mean & 11.59 & 182.10 \\
\hline
\end{tabular}

Charts 2 and 3 show annual cross-country average inflation and the penumbra of individual country annual inflation rates during the two periods. The cross-country average ranged between -5 percent in 1884 and +4 percent in 1912 in the earlier period., and between 2 
percent in 1993 and 12 percent in 1974 in the recent period. The jagged movement in individual country inflation rates from year to year in the earlier period is apparent in Chart 2. Year-to-year changes in inflation rates in individual countries were much smoother in the recent period as were the year-to-year changes in the cross country average of inflation rates.

\section{Chart 2. Annual CPI Inflation Rates, 1881-1913 Major Industrial Countries}

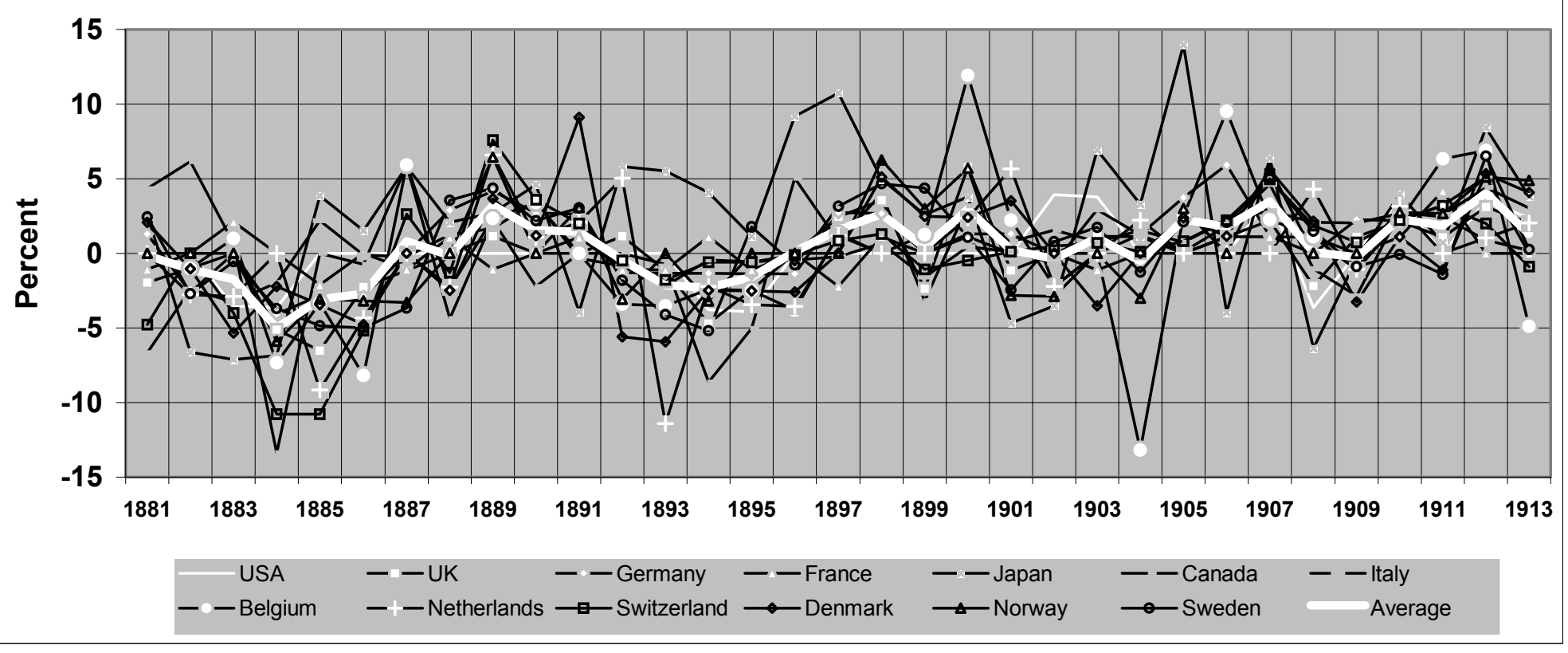

\section{Chart 3. Annual CPI Inflation Rates, 1963-1995 Major Industrial Countries}

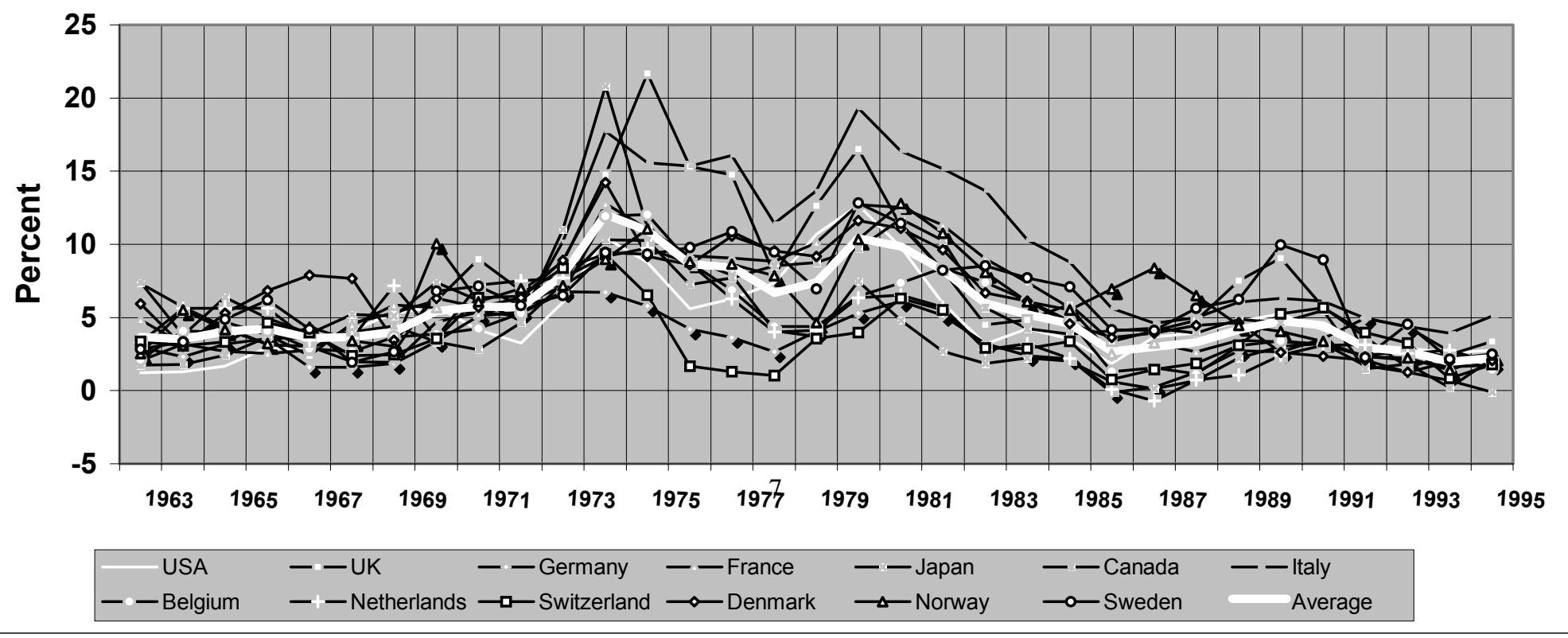




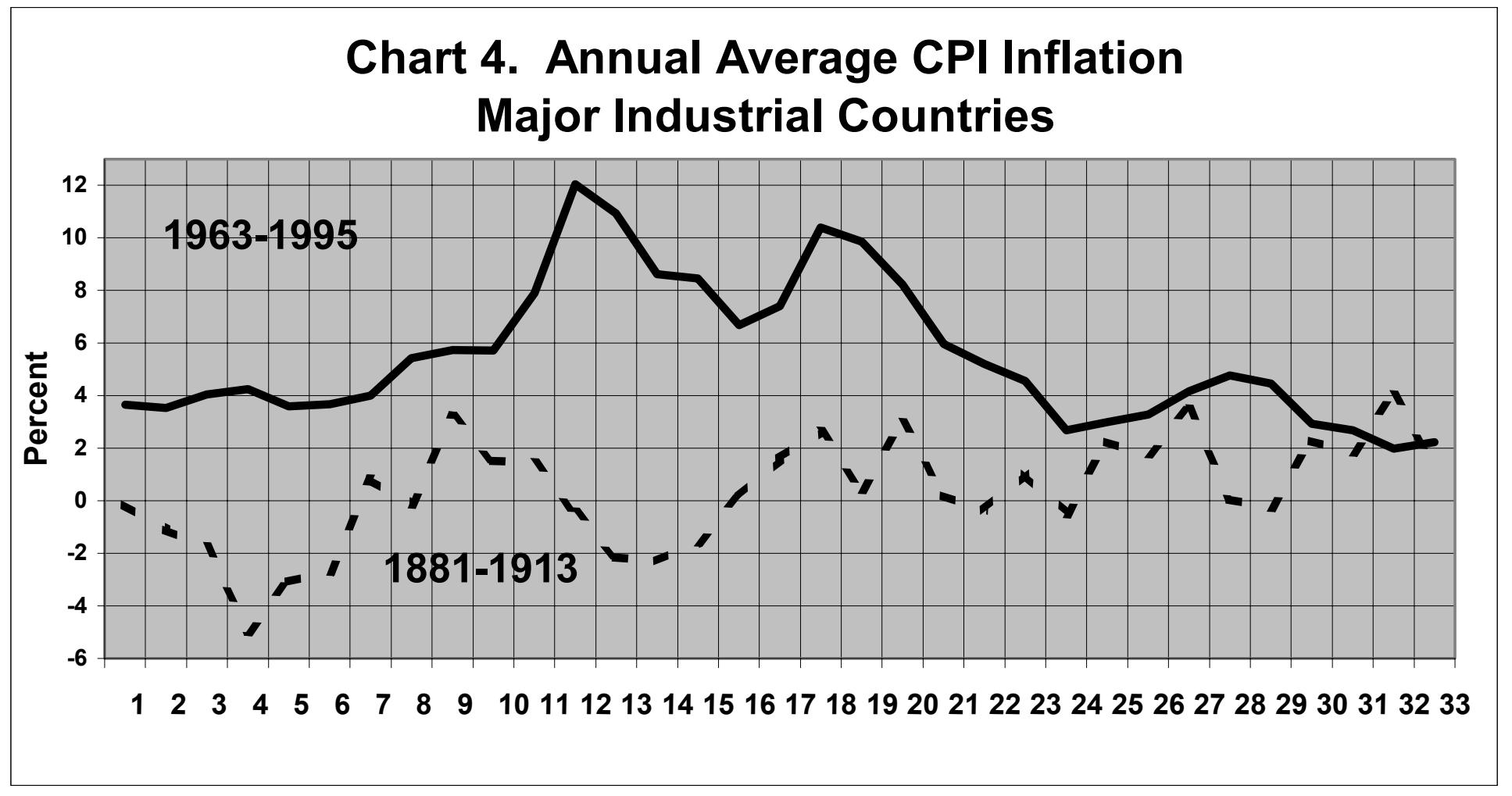

Chart 4 plots the cross-country averages of CPI inflation for the two periods. During 1881-1913 the inflation average rose and fell around zero early in the period but then increased to about 2 percent at the end of the period. During 1963-1995 the inflation average accelerated from about 4 percent early in the period to a peak of 12 percent in the mid-1970s but then cycled down to about 2 percent at the end of the period.

Table 3 shows that annual changes in inflation rates were comparably variable in the earlier as in the recent period. That inflation rates were higher in 1913 than 1881 is manifested in a positive average change in inflation rates in that period. In the recent period, inflation rates in 1995 were also slightly higher on average than in 1963, but, as noted, average inflation over the entire period was enormously higher. 


\begin{tabular}{|c|c|c|c|c|}
\hline \multirow[t]{2}{*}{ Country } & \multicolumn{2}{|c|}{$1881-1913$} & \multicolumn{2}{|c|}{ 1963-1995 } \\
\hline & Mean & Std Dev & Mean & Std Dev \\
\hline USA & 0.07 & 2.11 & 0.21 & 2.61 \\
\hline UK & -0.09 & 2.53 & 0.25 & 3.01 \\
\hline Germany & 0.83 & 2.40 & 0.14 & 2.21 \\
\hline France & 0.13 & 1.25 & 0.00 & 1.79 \\
\hline \begin{tabular}{|l|} 
Japan \\
\end{tabular} & 2.27 & 5.27 & 0.37 & 7.28 \\
\hline Canada & 0.64 & 4.03 & 0.56 & 5.00 \\
\hline |taly & 0.03 & 2.20 & 0.07 & 2.36 \\
\hline Netherlands & -0.26 & 3.70 & 0.07 & 5.34 \\
\hline Switzerland & -0.16 & 3.72 & 0.34 & 3.01 \\
\hline Denmark & 0.16 & 3.65 & 0.22 & 4.54 \\
\hline Norway & 0.55 & 3.25 & 0.37 & 3.99 \\
\hline Sweden & 0.37 & 3.19 & 0.14 & 3.53 \\
\hline Average & 0.35 & 3.25 & 0.22 & 3.96 \\
\hline
\end{tabular}

\section{BOND RATE COMPARISONS}

Table 4 illustrates how price level stability during 1881-1913 was reflected in bond markets in highly industrialized countries. Long-term rates averaged 3.58 percent and varied across countries within a narrow 1.35 percentage point range: from a low of 2.88 in the UK -the most developed country in that period -- to a high of 4.23 in Italy. It along with Japan was among the least developed at that time. The average standard deviation was 0.29 percentage points. Undoubtedly, the pre World War I era was one of remarkable stability and similarity of bond rates across the industrialized countries. 


\begin{tabular}{|c|c|c|c|c|c|c|}
\hline Country & \multicolumn{2}{|c|}{$1881-1913$} & \multicolumn{2}{|c|}{ 1963-1995 } & \multicolumn{2}{|c|}{ Differences } \\
\hline & Mean & Std Dev & Mean & Std Dev & Mean & Std Dev \\
\hline USA & 3.76 & 0.30 & 8.00 & 2.46 & 4.24 & 2.15 \\
\hline UK & 2.88 & 0.21 & 10.12 & 2.64 & 7.24 & 2.43 \\
\hline Germany & 3.68 & 0.18 & 7.67 & 1.30 & 3.99 & 1.12 \\
\hline France & 3.24 & 0.31 & 8.95 & 2.77 & 5.71 & 2.46 \\
\hline Japan & NA & NA & 6.61 & 1.75 & NA & NA \\
\hline Canada & 3.49 & 0.44 & 9.02 & 2.49 & 5.53 & 2.04 \\
\hline Italy & 4.23 & 0.46 & 10.84 & 4.30 & 6.60 & 3.84 \\
\hline Belgium & 3.19 & 0.24 & 8.59 & 2.09 & 5.40 & 1.85 \\
\hline Netherlands & 3.25 & 0.31 & 7.57 & 1.65 & 4.33 & 1.34 \\
\hline Switzerland & 3.72 & 0.26 & 4.81 & 0.96 & 1.09 & 0.70 \\
\hline Denmark & 3.71 & 0.20 & 11.22 & 3.58 & 7.51 & 3.38 \\
\hline Norway & 4.04 & 0.29 & 8.45 & 3.11 & 4.41 & 2.82 \\
\hline Sweden & 3.80 & 0.25 & 9.41 & 2.48 & 5.61 & 2.23 \\
\hline Mean & 3.58 & 0.29 & 8.56 & 2.43 & 4.97 & 2.14 \\
\hline
\end{tabular}

In sharp contrast to 1881-1913, during 1963-1995 the overall average of the bond rates was 8.56 percent and long-term interest rates ranged widely across the thirteen industrial nations. Switzerland had the lowest average at 4.81 percent. It along with Germany had the lowest inflation during 1963-1995. Denmark, Italy, Sweden, and the UK had the highest bond rates and inflation rates. The average standard deviation of bond rate across countries was 2.43 percentage points in the recent period, eight times as much as in the pre-World War I era. One can observe the essence of inflation credibility in Charts 4 and 5 which plot both individual country bond rates and cross-country averages. Chart 6 plots the cross-country averages for each of the 33 year periods. The charts show how extremely low and stable ten-year government bond rates were in the pre-World War I era across time and across countries compared with the higher level and variability of bond rates in the recent period. 


\section{Chart 4. Ten-Year Government Bond Rates, 1881-1913 Major Industrial Countries}
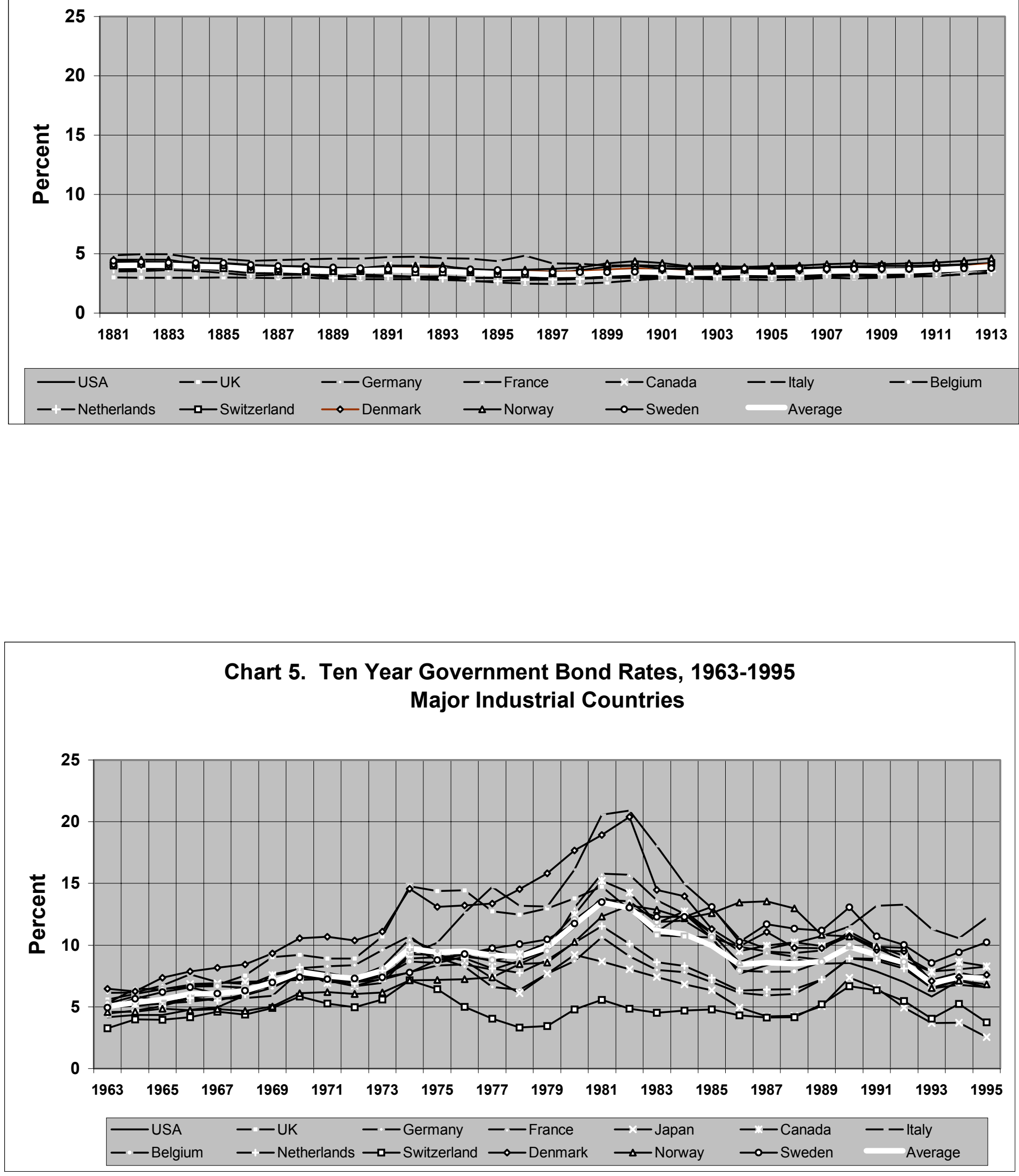
Chart 6. Cross-Country Average Ten-Year Government Bond Rates

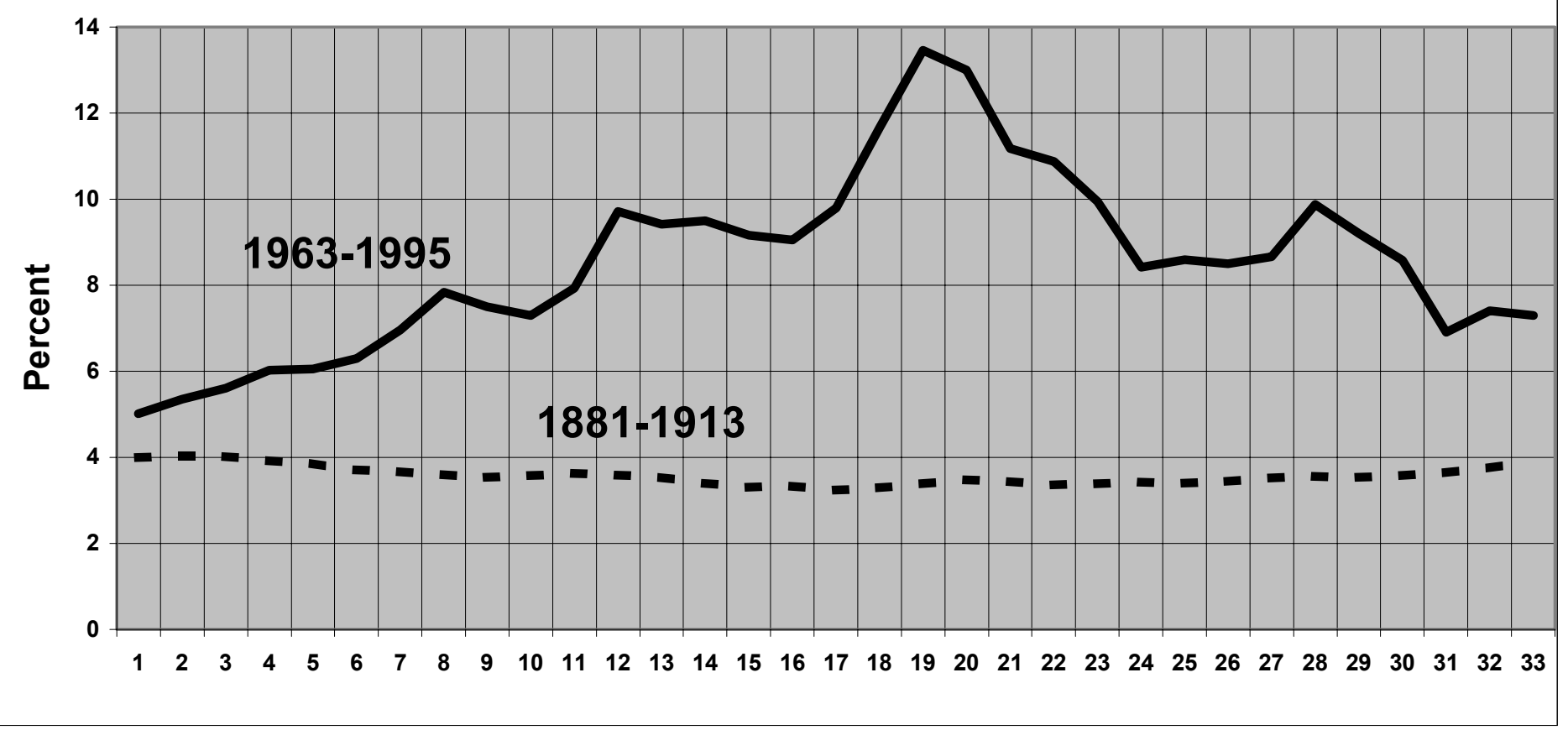

The comparative stability in bond rates is also shown in Table 5 which presents the individual country averages and standard deviations in year-to-year changes in bond rates during the two periods. The average standard deviation in annual percentage point changes in bond rates was 1.13 percentage points during 1963-1995, but only 0.12 percentage points during 1881-1913. No matter how you look at the data, bond rates were phenomenally stable across time and countries in the three decades before World War I. 


\begin{tabular}{|c|c|c|c|c|c|c|}
\hline \multirow[t]{2}{*}{ Country } & \multicolumn{2}{|c|}{$1881-1913$} & \multicolumn{2}{|c|}{ 1963-1995 } & \multicolumn{2}{|c|}{ Differences } \\
\hline & Mean & Std Dev & Mean & Std Dev & Mean & Std Dev \\
\hline USA & -0.02 & 0.14 & 0.07 & 1.10 & 0.08 & 0.96 \\
\hline UK & 0.01 & 0.08 & 0.07 & 1.15 & 0.06 & 1.07 \\
\hline Germany & 0.00 & 0.08 & 0.02 & 1.00 & 0.02 & 0.91 \\
\hline France & 0.00 & 0.10 & 0.08 & 1.27 & 0.08 & 1.17 \\
\hline Japan* & NA & NA & -0.15 & 1.02 & NA & NA \\
\hline Canada & -0.01 & 0.17 & 0.10 & 1.07 & 0.10 & 0.90 \\
\hline Italy & -0.04 & 0.17 & 0.21 & 1.68 & 0.25 & 1.51 \\
\hline Belgium & 0.01 & 0.10 & 0.07 & 1.03 & 0.05 & 0.93 \\
\hline Netherlands & -0.01 & 0.14 & 0.09 & 0.96 & 0.10 & 0.82 \\
\hline Switzerland & 0.00 & 0.13 & 0.02 & 0.84 & 0.01 & 0.70 \\
\hline Denmark & 0.00 & 0.11 & 0.04 & 1.62 & 0.04 & 1.52 \\
\hline Norway & 0.00 & 0.17 & 0.07 & 0.96 & 0.07 & 0.79 \\
\hline Sweden & -0.02 & 0.07 & 0.16 & 1.01 & 0.18 & 0.94 \\
\hline Mean & -0.01 & 0.12 & 0.06 & 1.13 & 0.07 & 1.01 \\
\hline
\end{tabular}

\section{Real GDP Growth Comparisons}

Table 6 presents means and standard deviations of real GDP growth in twelve industrial countries during 1881-1913 and in the entire thirteen during 1963-1995. The data for Japanese real GDP growth were not available before 1886. We also lack real GDP data for Belgium before World War I.. The table shows that the United States and Canada had the fastest growth in the period before World War I. They also experienced the greatest slowing in real growth in the recent period relative to the earlier period. Switzerland, Denmark and Sweden also experienced slower growth in the recent period than in the pre World War I period. France, Norway, and particularly Japan, which had had only mediocre real growth in the earlier period for which we have data, experienced substantially higher growth in the recent period. Among 
the eleven industrialized economies for which we had real GDP data for both periods, only Canada and Germany had above average growth rates during both periods.

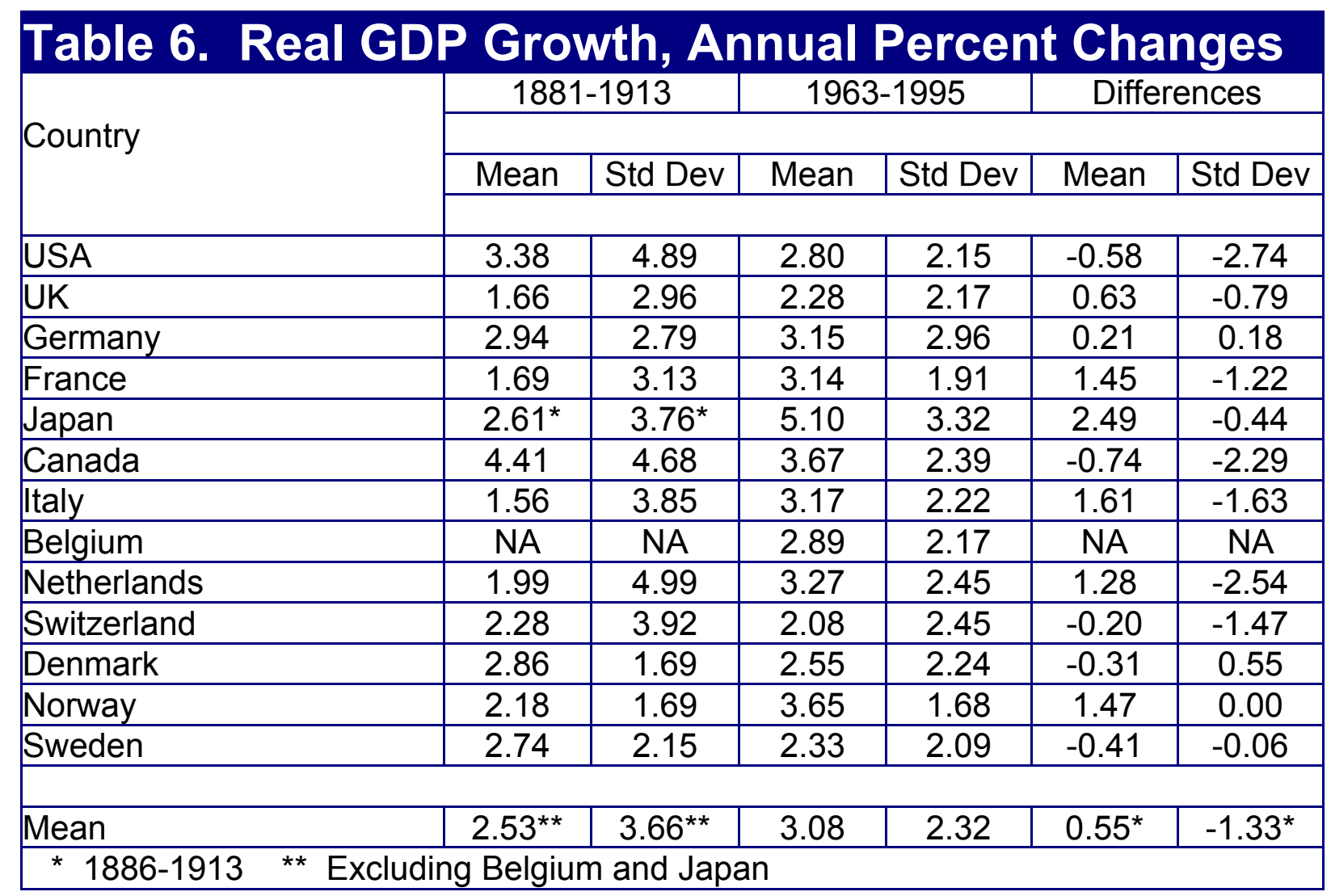

Charts 7 and 8 show annual cross-country averages of real GDP growth and the individual country growth rates for 1881-1913 and 1963-1995. Chart 9 plots the cross-country annual averages and the overall 33 year averages of real GDP growth for each period. The higher year-to-year volatility in real growth both individual country and cross-country observations in the earlier period is apparent in the charts. 
Chart 7. Real GDP Growth Rates, 1881-1913

Major Industrial Economies

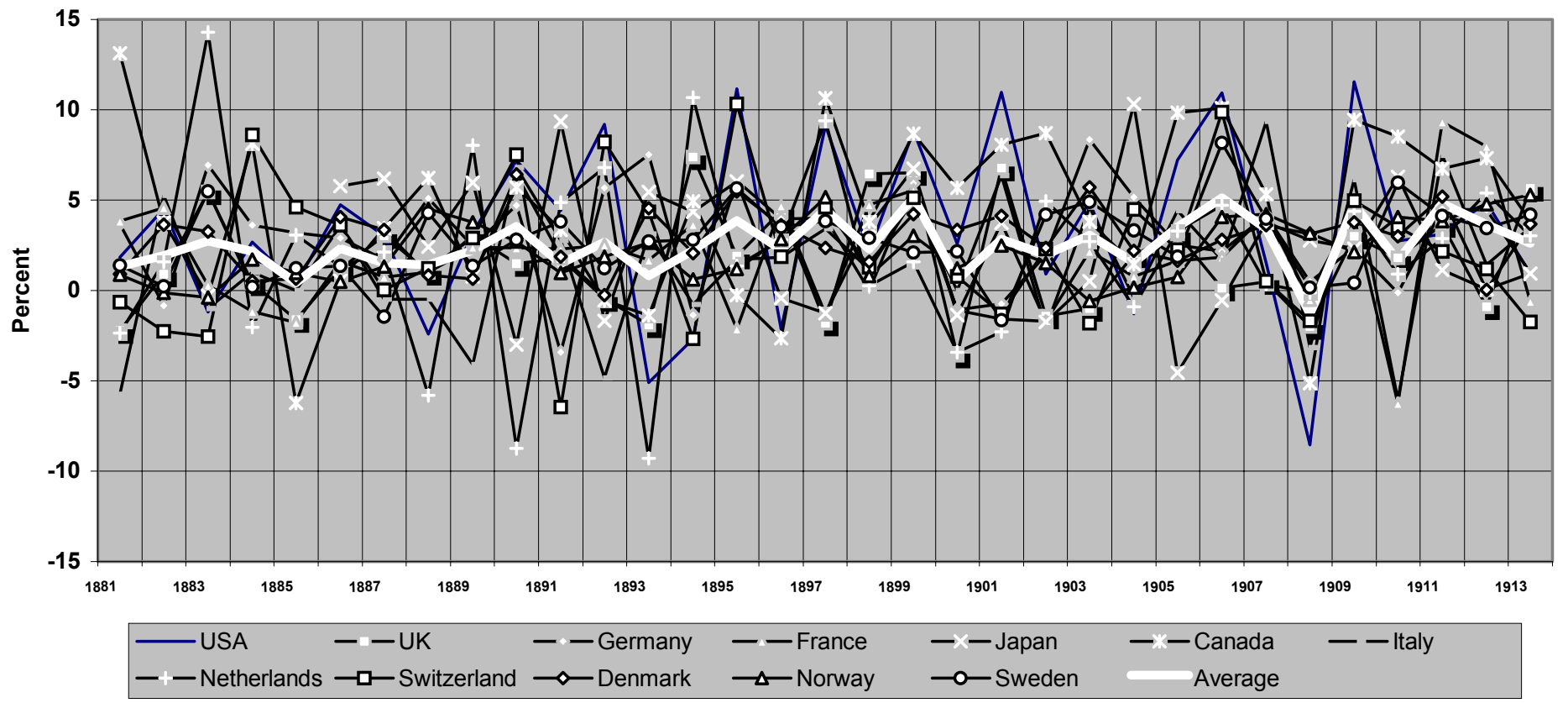

Chart 8. Real GDP Growth Rates. 1963-1995

Major Industrial Countries

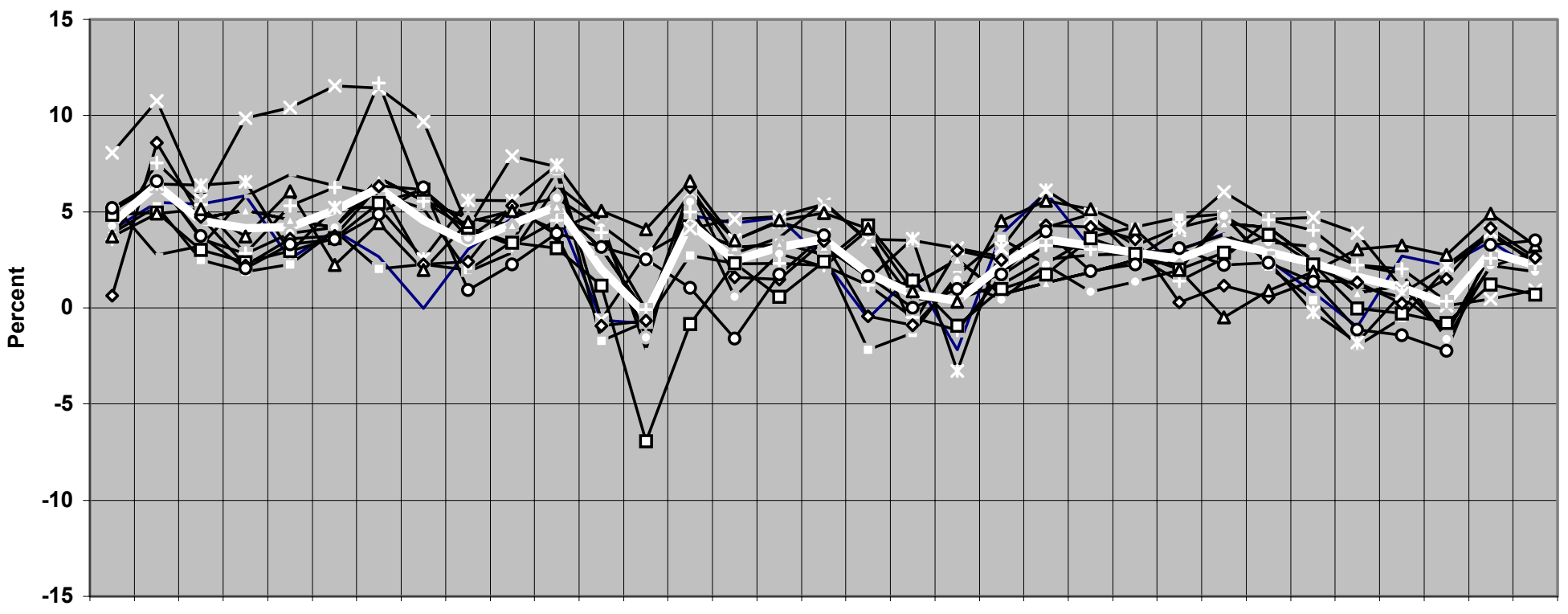

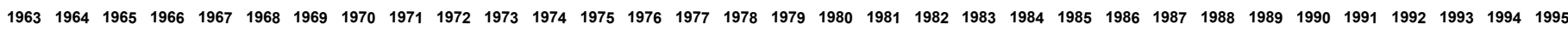

$$
\begin{aligned}
& \text { - USA - - UK - - Germany - - France -x-Japan - - Canada - - Italy }
\end{aligned}
$$

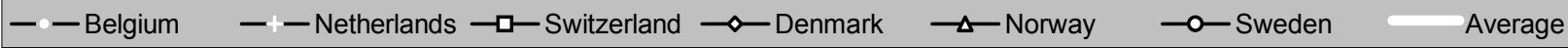




\section{Chart 9. Real GDP Growth, Cross-Country Averages}

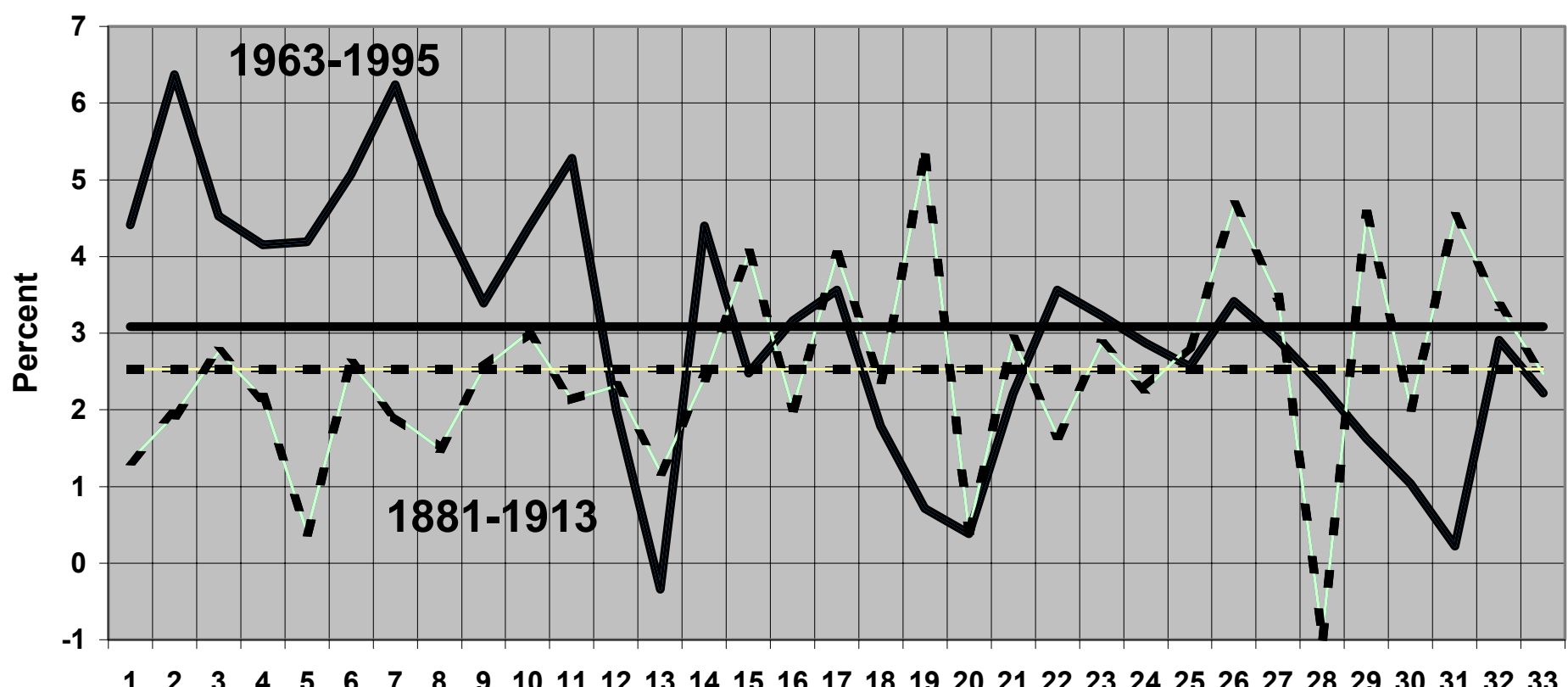

In our calculations of Fisher-Golden Rule bond market inflation expectations, average real growth rates represent prospective long-run investment opportunities. The cross-country average real GDP growth was 0.55 percentage point higher in the recent period than in the earlier period. Thus, within our framework, the increase in real growth trends would be reflected in a comparable increase in real interest rates. In fact, nominal interest rates on average were 4.98 percentage points higher in the recent than in the earlier period. We attribute the 4.43 percentage point discrepancy over 0.55 percentage points to an increase in bond market inflation expectations.

\section{Inflation Credibility}

The very low and stable long-term interest rate environment in major industrial countries during the years before World War I is a classic example of market credibility for long run price level stability. As noted, inflation was highly volatile from year to year, and the price level 
actually drifted up a little over the period in almost every industrial country. Yet, bond markets had sufficient faith that domestic currencies would hold their purchasing power in the long run that ten-year government bond rates did not generally change much in response to short-term movements in the price level.

By contrast, although some fared much worse than others, none of the central banks in major industrial countries kept its credibility to keep inflation low let alone price level stability in the recent period. Already in 1963, inflation among industrial countries averaged nearly 4 percent a year and long-term bond rates although averaging only 5 percent would soon rise sharply. Credibility to keep inflation low was being lost.

In the recent period the Swiss National Bank was the most successful in maintaining its credibility in bond markets to keep inflation low. In 1963 it had by far the lowest long-term interest rates among the thirteen industrial countries. When inflation accelerated worldwide during the 1970s, its long term bond rates rose less than those in other countries. In 1995 its longer-term bond rates were lower than long rates in every other country except Japan, which was in the midst of extended economic slow down and deflation. Although Germany also had comparatively low long-term bond rates during 1963-1995, it had higher rates than Switzerland, and its rates rose relative to those in other countries in the mid 1990s with the reunification of East and West Germany. Italy and the United Kingdom had the worst record in terms of not only inflation but also bond rate peaks. Even after inflation fell, their bond rates remained comparatively high relative to their inflation rates in 1995.

Charts 8,9 , and 10 compare bond rates, real GDP growth trends, and inflation in the United States, United Kingdom, and Switzerland for 1963-1995. Comparable data were presented in Chart 1 for the United States. Although average real GDP growth for Switzerland and the UK during this period were about the same, inflation and bond rates were not. Swiss 
bond rates ranged between 4 and 7 percent whereas UK bond rates ranged between 7 and 15 percent. The standard deviation of Swiss bond rates was 0.96 percentage points compared with 2.64 percentage points for the UK. Also plotted in these charts is the difference between the annual ten-year bond rate and the real growth rate trend during 1963-1995. In each case this proxy for bond market inflation expectations over the maturity of the bonds roughly parallels the average inflation rate during the previous ten years 


\section{Chart 10. Ten-Year Bond Rate, Real GDP Growth and Inflation Trends, 1963-1995 USA}

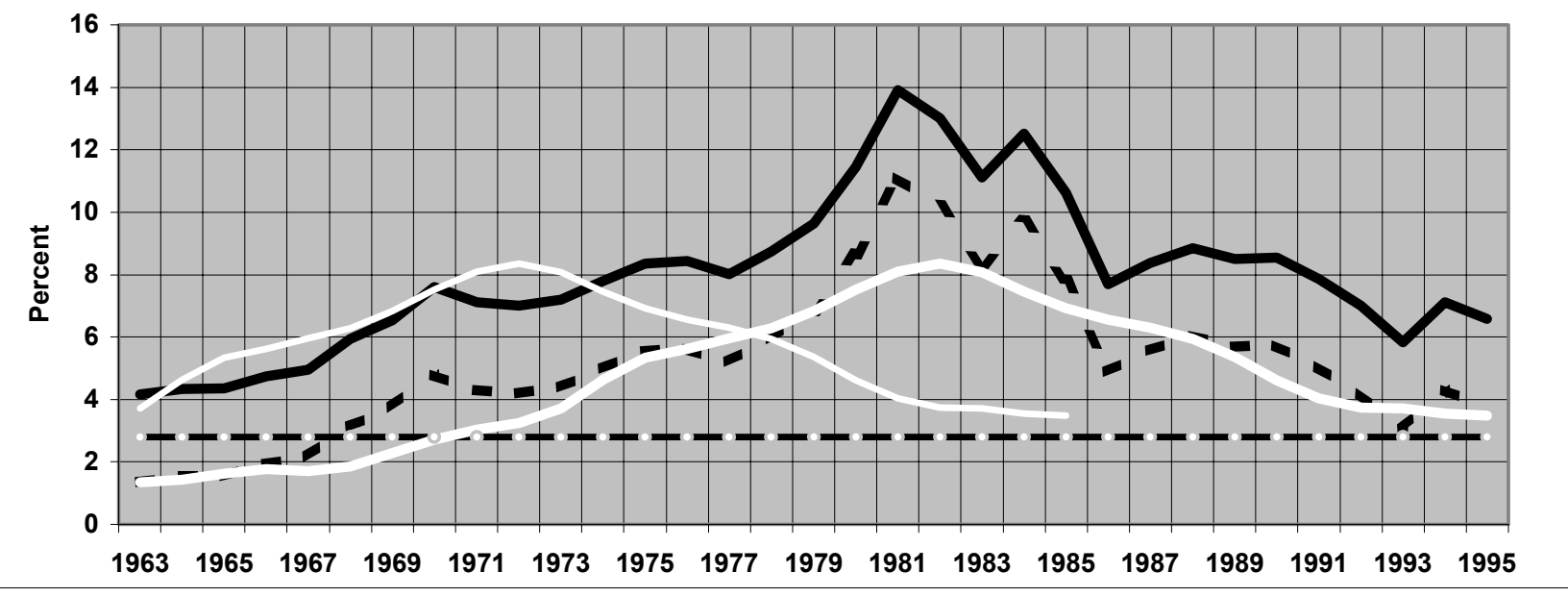

\section{UK}

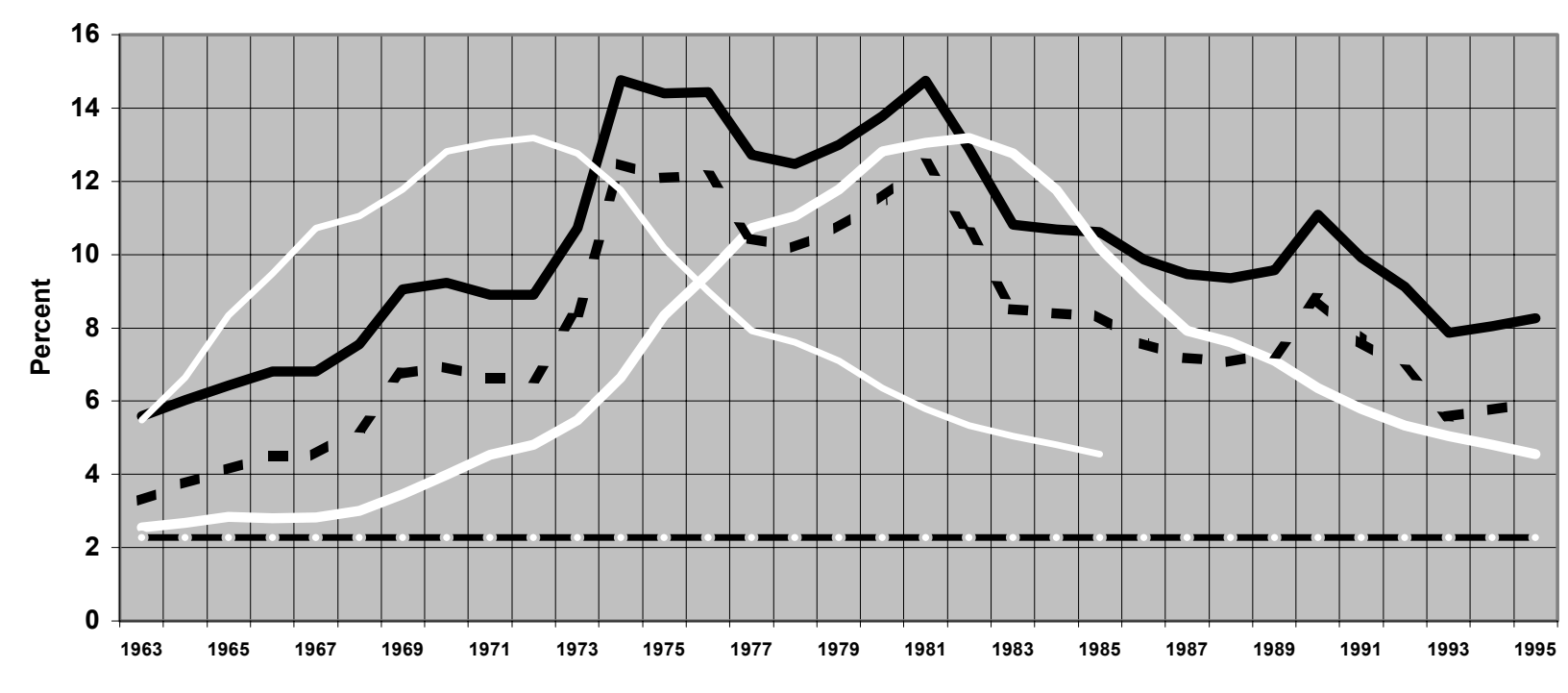

\section{Switzerland}

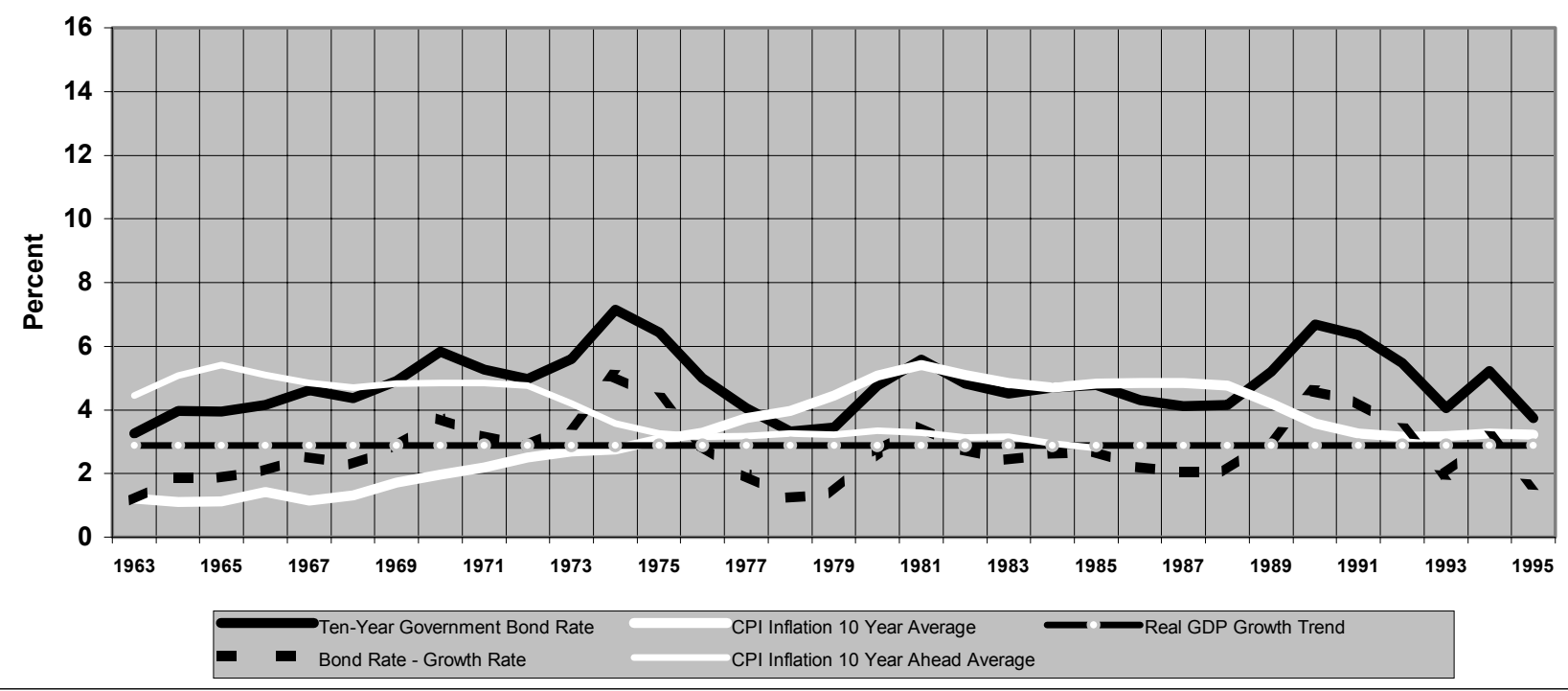




\section{BOND MARKET INFLATION EXPECTATIONS}

In a world of relatively free capital movements across national boundaries, long-term real interest rates in particular countries would reflect world investment and saving propensities, and nominal rates would reflect domestic inflationary prospects ${ }^{4}$. Countries with superior investment and real growth prospects would induce capital imports from the rest of the world. Their current account and trade balance deficits would reflect the capital inflow from nations that were saving more than they were investing domestically. Such a "World Growth Model" is the one used to generate the bond market inflation expectations that are reported in this paper ${ }^{5}$. In this approach the overall cross-country average real GDP growth rate for each of the periods is subtracted from individual country annual bond rates to calculate each country's bond market inflation expectations over the maturity of the bonds.

Tables 7 and 8 present cross-country averages of inflation ten years back and ten years ahead in columns 2 and 3. Column 4 is our calculated bond market expectations for average inflation over the ten-year maturity of the bonds. As noted, the expectation of inflation ten years ahead is calculated by subtracting the overall cross-country average real growth rate from each

\footnotetext{
${ }^{4}$ Under a fixed exchange rate regime such as the pre World War I gold standard, price levels in individual countries were highly interdependent. Nonetheless, even then each country had its own currency the value of which could in principle be affected by the amount of currency that was issued. The burst of inflation that occurred $\mathrm{n}$ World War I illustrates this point.

${ }^{5}$ In a world of relatively restricted capital movements across national boundaries, one would hypothesize that longer-term real interest rates in a particular country would reflect its own domestic investment and saving propensities, and its nominal rates would reflect its own domestic inflationary prospects. Such a "Country Growth Model" was used to generate one set of bond market inflation expectations which is not reported in the present paper. In this approach the individual country overall average real GDP growth rate for each period are subtracted from annual bond rates to calculate bond market inflation expectations over the life of the bond. The results were much the same as the results that are reported
} 
country's annual bond rate. Columns 5 and 6 record the expectations deviations from inflation over the ten-year maturity of the bonds and over the previous ten years. ${ }^{6}$

Although there are many other factors that affect inflation expectations, bond market inflation expectations as measured averaged about one percentage point during 1880-1913 when longer-term inflation averaged close to zero. One can speculate about the source of this discrepancy. It might reflect that measured real output growth was systematically underestimated. It might reflect a default risk premium in an environment where governments could default on debt in a gold standard world. It might reflect that bond markets, even in an age when inflation was low and widely expected to stay low, had a foreboding that inflation might burst forth again as in many historical episodes. For whatever reason, average bond rates were about a percentage point higher than real GDP growth rates before World War I. During 19621995, bond market inflation expectations as measured averaged close to lagged actual inflation.

Thus, the Fisherian-Golden Rule measure of bond market inflationary expectations appears to have captured a fundamental market relationship between bond rates, real GDP growth rates, and inflation that holds up quite well on average over thirty-three year periods across vastly different eras in terms of monetary regimes, technological and cultural developments, etc. Nevertheless, as Tables 7 and 8 show, these bond market inflation expectations systematically failed to perceive major changes in inflation trends.

\footnotetext{
${ }^{6}$ Calculations were also made on the assumption that the effective maturity of the 10 -year bonds was only five years. Results were comparable in finding that in both periods inflation expectations implicit in bond rates were closely linked to past not future inflation and therefore accurate only when inflation did not change.
} 


\begin{tabular}{|c|c|c|c|c|c|}
\hline & \multicolumn{3}{|c|}{ Inflation } & \multicolumn{2}{|c|}{ Deviation } \\
\hline & $\begin{array}{c}10 \text { Years } \\
\text { Back }\end{array}$ & $\begin{array}{l}10 \text { Years } \\
\text { Ahead }\end{array}$ & $\begin{array}{c}\text { Expectations } \\
\text { Over Bond } \\
\text { Maturity }\end{array}$ & $\begin{array}{c}10 \text { Years } \\
\text { Back }\end{array}$ & $\begin{array}{c}10 \text { Years } \\
\text { Ahead }\end{array}$ \\
\hline 1880 & & -0.92 & 1.50 & & 2.42 \\
\hline 1881 & & -0.70 & 1.40 & & 2.10 \\
\hline 1882 & & -0.73 & 1.44 & & 2.16 \\
\hline 1883 & & -0.87 & 1.43 & & 2.30 \\
\hline 1884 & & -0.67 & 1.33 & & 2.01 \\
\hline 1885 & & -0.49 & 1.27 & & 1.75 \\
\hline 1886 & & -0.25 & 1.11 & & 1.36 \\
\hline 1887 & & -0.20 & 1.08 & & 1.28 \\
\hline 1888 & & 0.07 & 1.01 & & 0.94 \\
\hline 1889 & & -0.23 & 0.94 & & 1.17 \\
\hline 1890 & -0.92 & -0.07 & 0.98 & 1.90 & 1.04 \\
\hline 1891 & -0.70 & -0.20 & 1.04 & 1.74 & 1.24 \\
\hline 1892 & -0.73 & -0.11 & 0.99 & 1.72 & 1.10 \\
\hline 1893 & -0.87 & 0.22 & 0.94 & 1.81 & 0.72 \\
\hline 1894 & -0.67 & 0.42 & 0.81 & 1.48 & 0.39 \\
\hline 1895 & -0.49 & 0.73 & 0.71 & 1.20 & -0.02 \\
\hline 1896 & -0.25 & 1.02 & 0.74 & 0.98 & -0.28 \\
\hline 1897 & -0.20 & 1.26 & 0.65 & 0.85 & -0.61 \\
\hline 1898 & 0.07 & 1.07 & 0.69 & 0.62 & -0.38 \\
\hline 1899 & -0.23 & 1.03 & 0.80 & 1.02 & -0.23 \\
\hline 1900 & -0.07 & 0.95 & 0.89 & 0.95 & -0.06 \\
\hline 1901 & -0.20 & 1.08 & 0.85 & 1.05 & -0.23 \\
\hline 1902 & -0.11 & 1.46 & 0.77 & 0.88 & -0.69 \\
\hline 1903 & 0.22 & 1.51 & 0.79 & 0.57 & -0.72 \\
\hline 1904 & 0.42 & 1.69 & 0.84 & 0.42 & -0.86 \\
\hline 1905 & 0.73 & 2.83 & 0.80 & 0.07 & -1.99 \\
\hline 1906 & 1.02 & 4.21 & 0.85 & -0.17 & -3.29 \\
\hline 1907 & 1.26 & 5.79 & 0.93 & -0.33 & -4.81 \\
\hline 1908 & 1.07 & 7.99 & 0.97 & -0.11 & -7.06 \\
\hline 1909 & 1.03 & 9.39 & 0.94 & -0.08 & -8.50 \\
\hline 1910 & 0.95 & 11.72 & 0.98 & 0.03 & -10.74 \\
\hline 1911 & 1.08 & 10.84 & 1.05 & -0.03 & -9.79 \\
\hline 1912 & 1.46 & 11.36 & 1.15 & -0.30 & -10.21 \\
\hline 1913 & 1.51 & 28.65 & 1.30 & -0.21 & -27.34 \\
\hline Mean & 0.22 & 2.94 & 1.00 & 0.67 & -1.94 \\
\hline Standard Deviation & 0.79 & 5.88 & 0.23 & 0.74 & 5.87 \\
\hline RMS Based on Indiv & al Country E & 1s Deviati & & 1.14 & 13.86 \\
\hline
\end{tabular}




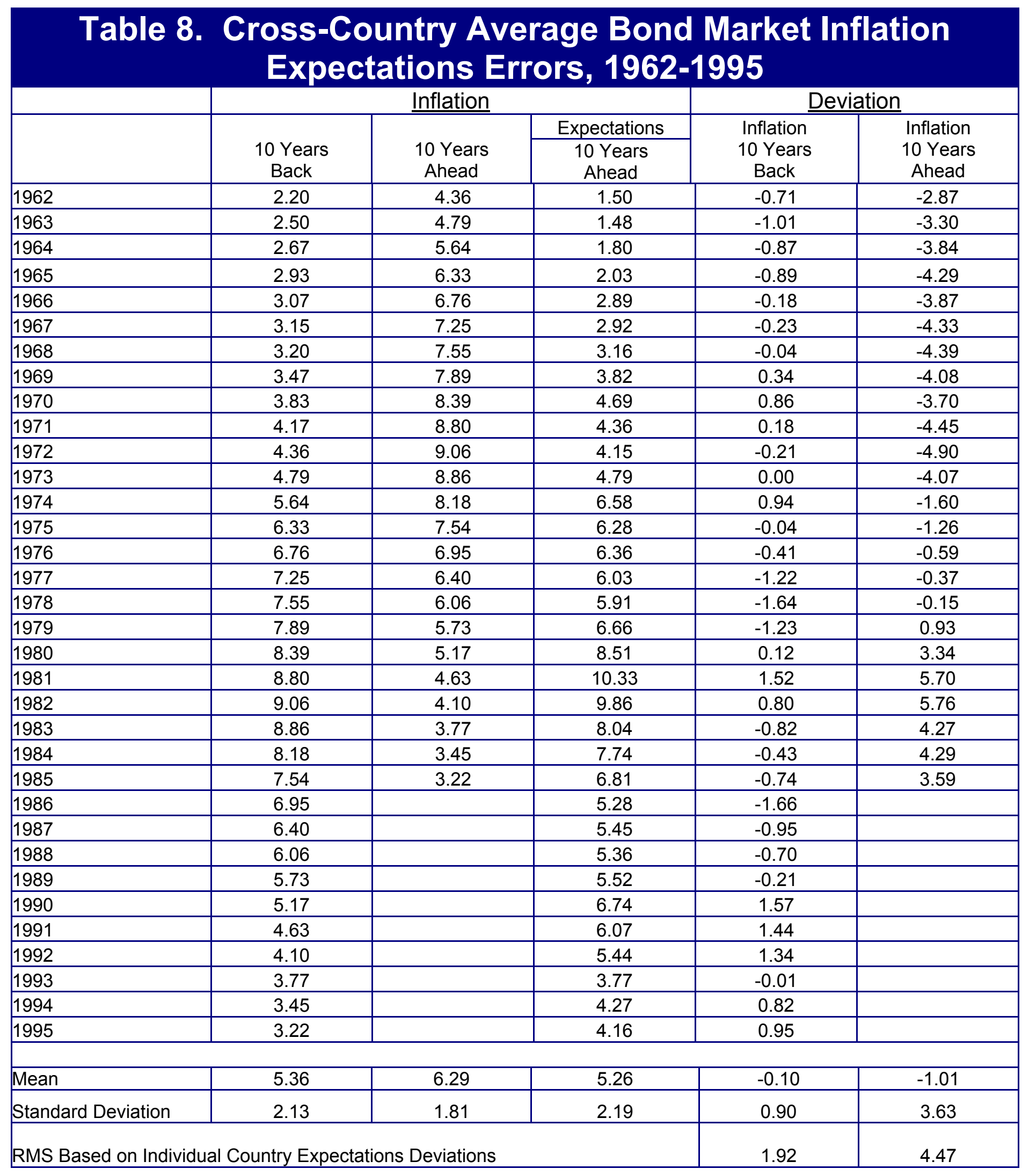




\section{Chart 10. Bond Market Inflation Expectations Errors}

\section{Major Industrial Country Averages}

\section{1-1913}

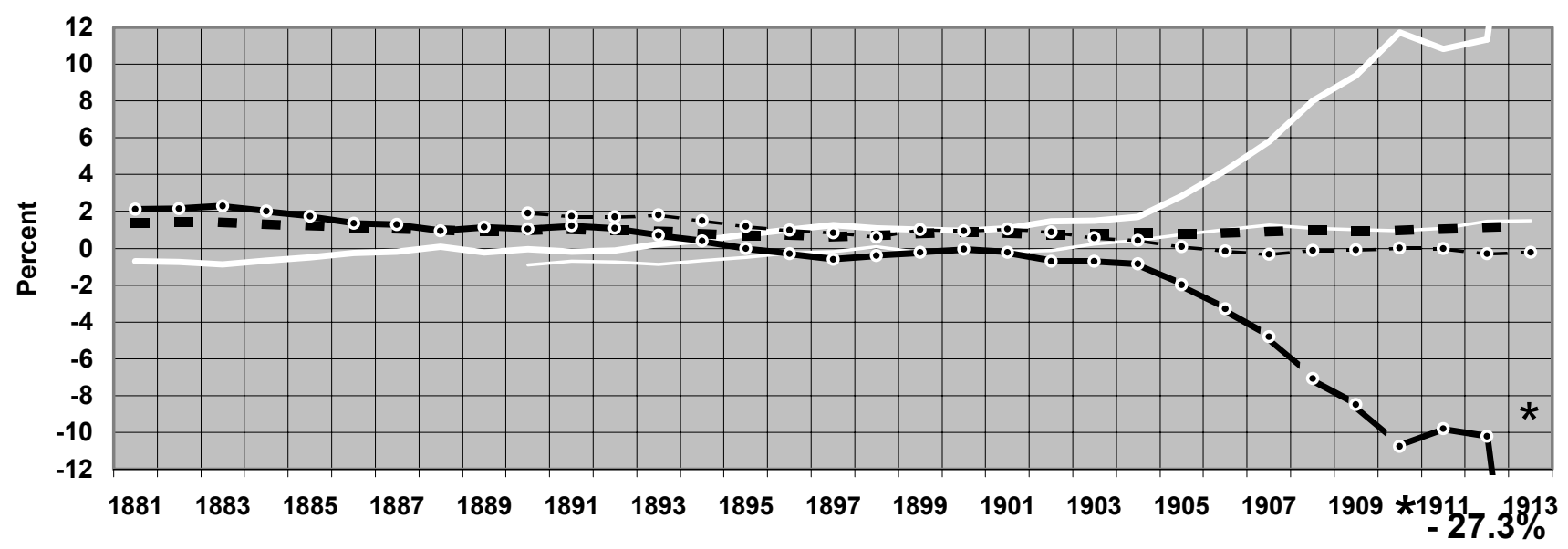

1962-1995

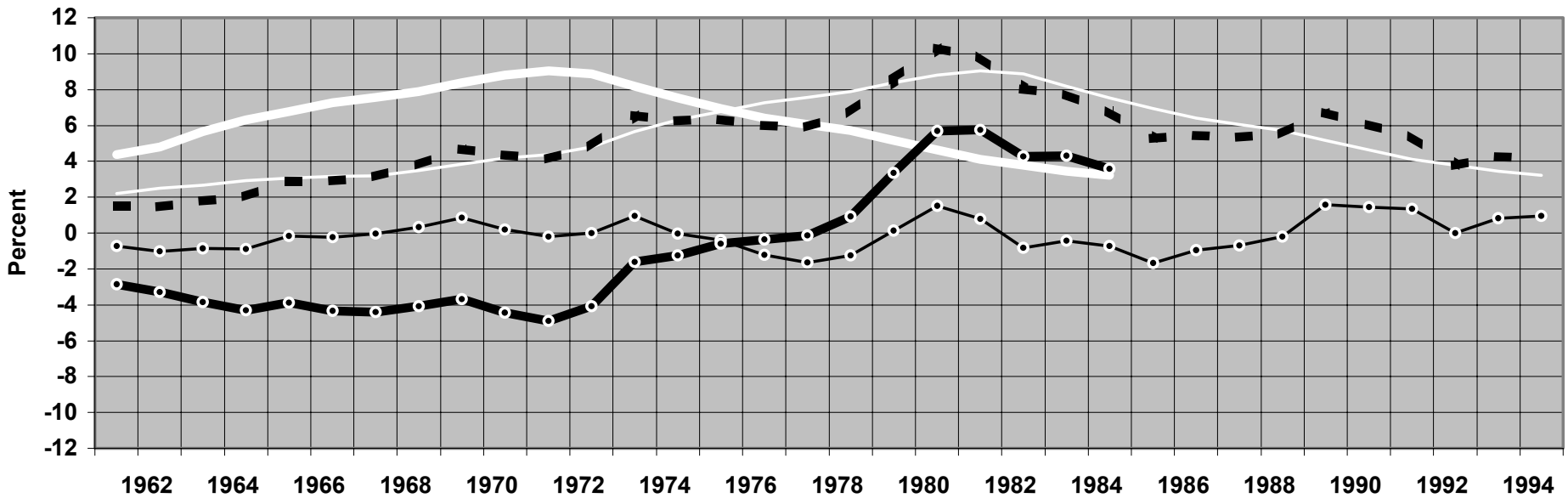


The information in Tables 7 and 8 is presented in Chart 10 which shows cross-country averages of inflation ten years ahead and the cross-country average of measured bond market ten-year-ahead inflation expectations. The chart shows that for the period before 1903 bond market inflation expectations based on the cross-country average real GDP growth rate for the entire period are remarkably low and stable. Nonetheless, bond markets -- which is not surprising -- did not anticipate the surges of inflation that occurred during World War I let alone the German hyper inflation in the early 1920s. ${ }^{7}$

For the recent period the lower panel of the chart shows that bond market inflation expectations missed the mark badly both when inflation accelerated early in the period and again when it decelerated. The ten-year cross-country average of inflation held at 6 percent or more from 1975 through 1988 and the ten-year-ahead average from 1965 through 1978. The peak in the cross-country average of bond market ten-year-ahead inflation expectations in 1981 and 1982 was well above what actually happened to inflation. Bond markets continued to over forecast inflation through 1985, the last observations plotted.

$7 \quad$ One of the benefits to governments that have established credibility to keep inflation low is that, if they choose, they can exploit bond holders by creating an inflation that reduces the real value of outstanding bonds. Credibility allows the inflation tax to generate large revenues because real balances do not decline as much as they would if credibility were low. 


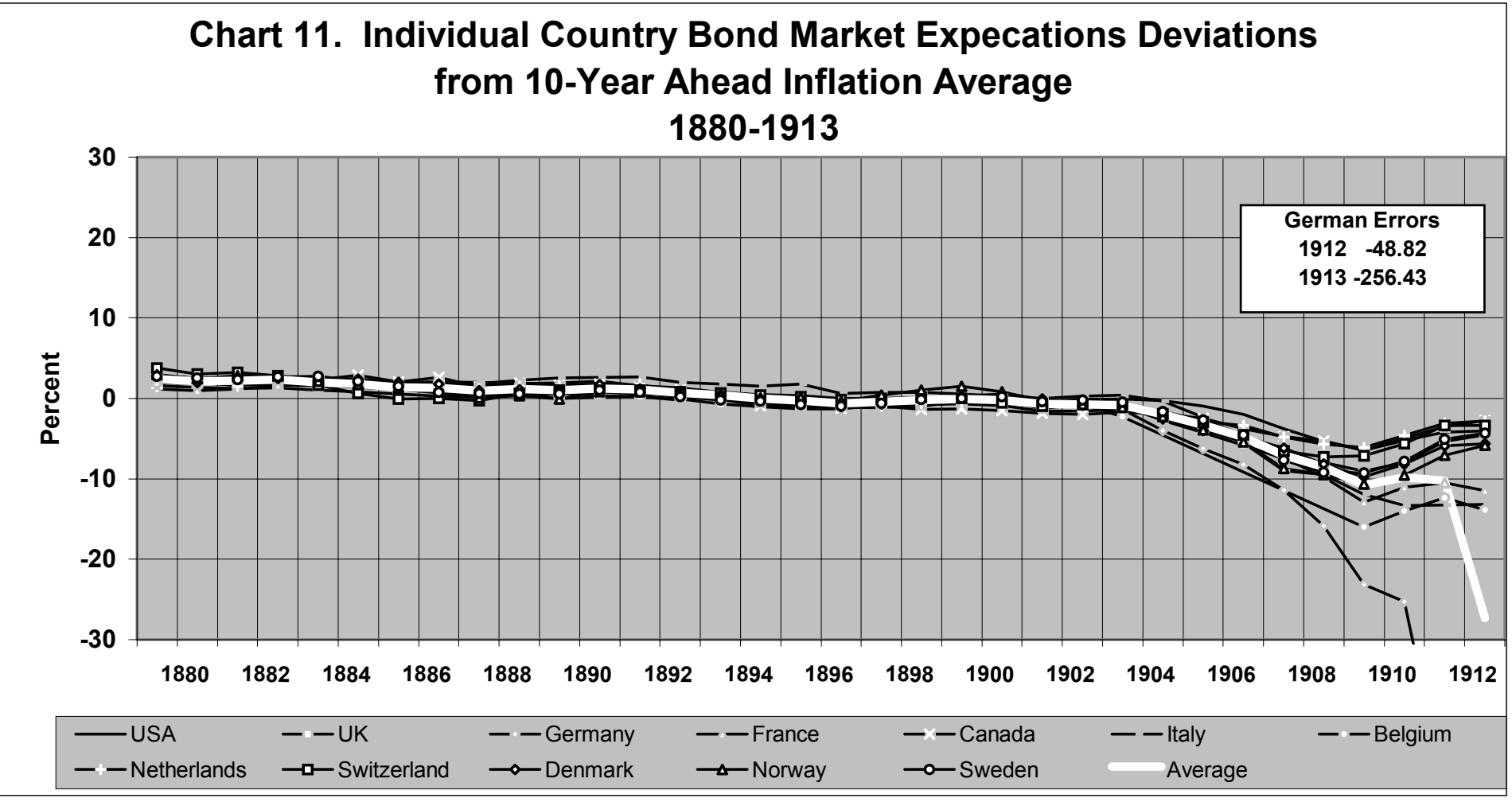

\section{Chart 12. Individual Country Bond Market Expectations Deviations from 10-Year Ahead Inflation Average 1962-1985}

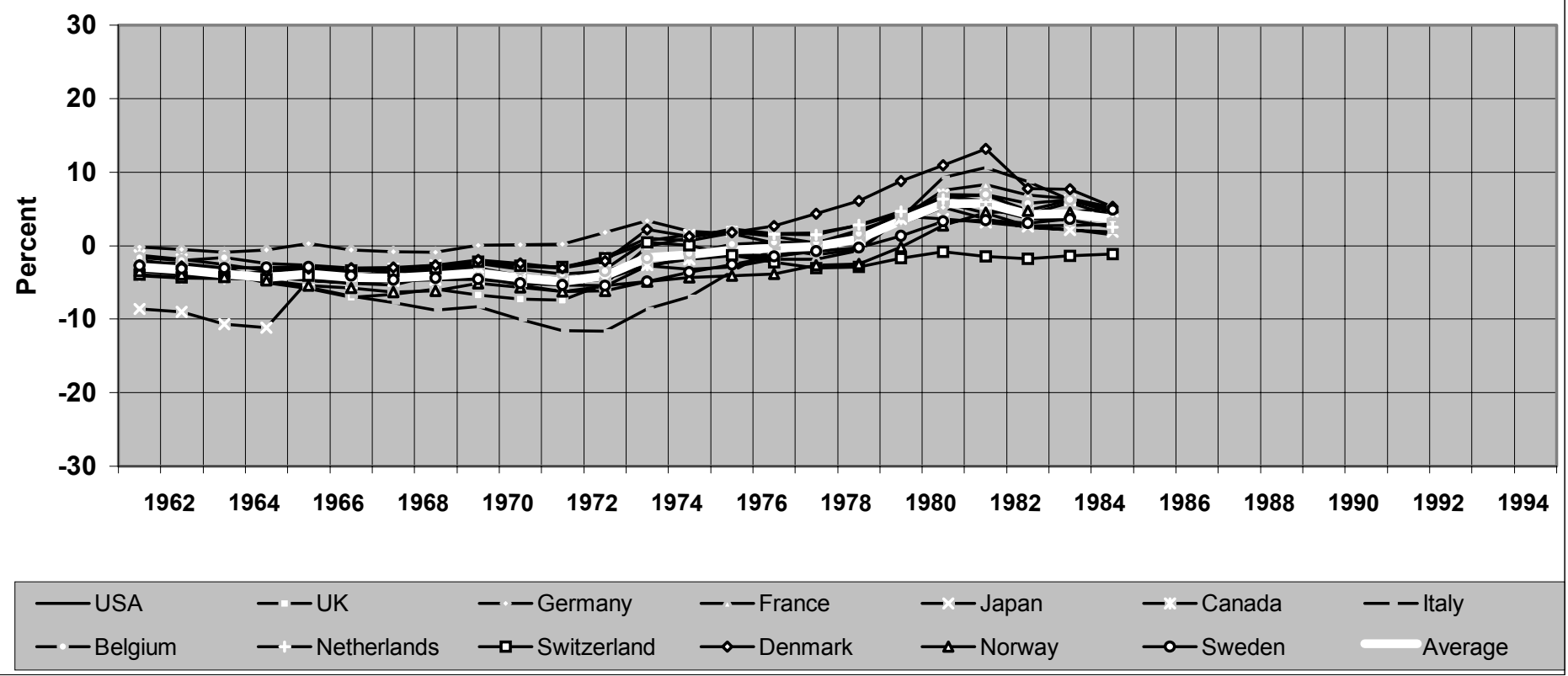


Chart 13 and 14 show cross-country average and individual country 10-year-ahead inflation expectations errors. The charts show that there was more variation across countries in bond market inflation forecast errors in the second period than the first period.. In both periods, there was considerable similarity in the errors across countries. That seems a reasonable expectation in the fixed exchange regime in the first period. One might have expected individual countries to go their own way with respect to inflation in a flexible exchange rate environment which existed through much of the recent period. In fact, there were wide differences between the inflation rates and bond market inflation expectations of future inflation across the spectrum of the thirteen industrialize countries included in our study. Nevertheless, the pattern of bond markets systematically expecting inflation to be what it had been is reflected in both periods and in every nation. Each systematically missed the surge of inflation in World War I, the acceleration of inflation in the 1970s, and the deceleration of inflation in the 1980s and 1990s.

Table 9 presents the root mean square errors of bond market 10 year ahead inflation expectations compared with the actual average of inflation 10 years ahead. The table demonstrates that expectations errors were lower in an environment of comparative price stability such as in 1880-1903 before the inflation during World War I made bond market tenyear ahead inflation forecasts go awry. The average root mean square error of the ten year ahead bond market inflation expectations in the period $1880-1903$ was only 1.43 percentage points. The root mean square error for the overall $1884-1913$ period was 7.42 percentage points, hugely influenced by the post World War I German hyperinflation. For every other country than Germany the root mean square errors for 1962-1995 were higher than for the pre World War I era. The average root mean square error for 1962-1995 was 4.30 percentage points which is three times the ten year ahead bond market inflation expectations error rate in the stable inflation environment of the late $19^{\text {th }}$ Century. 


Table 9. Bond Market 10 Year Ahead Inflation Expectations
\begin{tabular}{|l|c|c|c|}
\hline \multicolumn{4}{|c|}{ Root Mean Square Errors (Percentage Points) } \\
\hline & $1880-1903$ & $1880-1913$ & $1962-1985$ \\
\hline USA & 1.64 & 2.53 & 3.85 \\
\hline UK & 1.13 & 3.50 & 4.71 \\
\hline Germany & 0.99 & 46.00 & 1.97 \\
\hline France & 0.96 & 4.75 & 4.85 \\
\hline Japan & NA & NA & 5.22 \\
\hline Canada & 1.88 & 2.72 & 3.88 \\
\hline Italy & 1.84 & 5.38 & 7.17 \\
\hline Belgium & 1.38 & NA & 3.71 \\
\hline Netherlands & 1.47 & 2.49 & 3.64 \\
\hline Switzerland & 1.51 & 2.94 & 2.83 \\
\hline Denmark & 1.54 & 3.63 & 5.48 \\
\hline Norway & 1.44 & 4.09 & 4.80 \\
\hline Sweden & 1.43 & 3.54 & 3.75 \\
\hline \multicolumn{4}{|l|}{} \\
\hline Mean & 1.43 & 7.42 & 4.30 \\
\hline
\end{tabular}

\section{Monetary Growth}

Although the emphasis of this paper is not directly on the relationship between monetary growth and inflation', Table 10 shows that M2 growth was lower in every country and on average during the low inflation pre World War I period than during the high inflation recent period. M2 growth increased 4.93 percentage point from the first to the second period which is comparable with the 5.17 percentage point increase in inflation between the two periods. This observation is consistent with the Quantity Theory concept that inflation is fundamentally a monetary phenomenon.

\footnotetext{
${ }^{9}$ See our companion paper (2001) "Historical Monetary Growth and Inflation Cycles in Major Countries, 18801995".
} 


Table 10. M2 Growth
\begin{tabular}{|l|c|c|c|}
\hline Country & $1880-1913$ & $1962-1995$ & Difference \\
\hline \multicolumn{4}{|l|}{} \\
\hline USA & 6.20 & 7.57 & 1.38 \\
\hline UK & 2.19 & 12.69 & 10.50 \\
\hline Germany & 5.40 & 8.46 & 3.07 \\
\hline France & 2.63 & 9.37 & 6.74 \\
\hline Japan & 5.12 & 9.97 & 4.84 \\
\hline Canada & 7.12 & 10.51 & 3.39 \\
\hline Italy & 3.25 & 11.23 & 7.99 \\
\hline Belgium & 2.88 & 5.69 & 2.81 \\
\hline Netherlands & 1.73 & 7.82 & 6.09 \\
\hline Switzerland & 4.04 & 6.69 & 2.65 \\
\hline Denmark & 4.72 & 9.34 & 4.62 \\
\hline Norway & 4.89 & 10.31 & 5.42 \\
\hline Sweden & 5.44 & 9.98 & 4.55 \\
\hline \multicolumn{4}{|l|}{} \\
\hline Mean & 4.28 & 9.20 & 4.93 \\
\hline
\end{tabular}

\section{Conclusion}

The Fisherian-Golden Rule concept of bond market inflationary expectations has provided a consistent framework for interpreting the historical data discussed in this paper. The difference between average longer-term bond rates and average real GDP growth rates reflected the widespread expectation of low inflation during 1881-1913 in all of the industrial countries included in our study. Bond rates were closely clustered with the UK anchoring the international gold standard monetary system with the lowest bond rates throughout that period. Ten- yearahead bond market inflation expectations fit the actual experience well through 1903, but then understandably failed to foresee the surge of inflation that occurred with the advent of World War I ten years hence.

Although real GDP growth was somewhat higher on average during 1962-1995 than 1881-1913, bond rate averages were considerably higher, roughly comparable with the higher 
inflation and monetary growth rates that were observed. The recent period was one when fixed exchange rates in terms of the U.S. dollar under Bretton Woods were abandoned in the 1970s under inflationary pressures attributable to accelerating monetary growth in the United States and other industrial countries. The narrow band of longer-term interest rates that existed among the industrial countries in the mid-1960s widened significantly in the 1970s and early 1980s as did inflation patterns. Led by Japan, Germany, Netherlands, and Switzerland, monetary growth, inflation, and long-term bond rates fell across the spectrum of the industrial countries in the 1980s and 1990s. Bond market expectations for low inflation were substantially, but not fully, regained by the industrial countries as a group.

Financial journalists have repeatedly cited the low longer-term interest rates in recent years as at historically low levels which is not true. Taking a much broader sweep of history, long-term interest rates in every industrial country today - except Japan - are higher now than they were in the pre World War I period. Furthermore, in most industrial countries and, in particular the United States, long-term interest rates are higher today than they were in the 1960s before the long inflation-disinflation cycle of the past 40 years got underway. That observation might reflect higher real growth prospects but on the basis of the historical record discussed in this paper, we suspect it reflects that bond markets have not fully adapted to the low inflation of recent years. Bond markets have forecast inflation accurately only when it has not changed much which is a reason for central banks to use their powers to keep inflation low and in principle eliminate it. 


\section{References}

Bergman, U. Michael, Michael D. Bordo, and Lars Jonung (1998) "Historical Evidence on Business Cycles: The International Experience," in Jeffrey C. Fuhrer and Scott Schuh (Eds.) Beyond Shocks: What Causes Business Cycles? Federal Reserve Bank of Boston, Finance Series No. 42, June.

Bordo, Michael D. (1993) "The Gold Standard, Bretton Woods, and Other Monetary Regimes: A Historical Appraisal," in Dimensions of Monetary Policy: Essays in Honor of Anatole B. Balbach, Federal Reserve Bank of St. Louis Review (Special Issue). April/May, pp. 121-191.

and Anna J. Schwartz (1997) "Monetary policy Regimes and Economic Performance: The Historical Record,” NBER Working Paper No. 6201, October.

and William G. Dewald (1999) "Bond Market Inflation Expectations Under Alternative Monetary Regimes: A Cross-Country Comparison" Western Economic Association Conference, July 8, 1999 and the Joint Money/Macro Workshop, Center for the Study of American Business and the Federal Reserve Bank of St. Louis, September 1, 1999.

Dewald, William G. (1998a) "Inflation, Real Interest Tax Wedges, and Capital Formation," Federal Reserve Bank of St. Louis Review, January/February, pp. 29-35.

(1998b) "Historical U.S. Monetary Growth, Inflation, and Inflation Credibility" Federal Reserve Bank of St. Louis Review, November/December, pp.13-23.

and Michael D. Bordo (2001), "Historical Monetary Growth and Inflation Cycles in Major Countries, 1880-1995” Western Economic Association Meetings, July, 2001.

McKinnon, Ronald I. (1998) "The International Gold Standard without Gold", Chapter 2 in The Rules of the Game: International Money and Exchange Rates, Cambridge, MA: MIT Press, pp. 111-136.

Taylor, John (1993) "Discretion versus policy rules in practice," Carnegie-Rochester Conference Series on Public Policy 39, pp. 195-214. 